\title{
WŁASNOŚĆ KOMUNALNA A WŁASNOŚĆ WSPÓLNA Z PERSPEKTYWY SOCJOLOGICZNEJ
}

\section{WŁASNOŚĆ W SENSIE PRAWNICZYM I SOCJOLOGICZNYM}

Prawnicze ujęcie własności jest historycznie starsze, wywodzi się bowiem z doktryn prawniczych starożytnego Rzymu, jako przesłanka rozstrzygnięć sądowych zaś przenikało przez stulecia do praktyki gospodarczej i myślenia potocznego. Wyraża się ono w dwóch związanych ze sobą formach. Po pierwsze, za rozstrzygające o charakterze i podziale własności uznaje ono aktualnie istniejące prawo i gwarantowane przez nie tytuły własności. Jest to koncepcja najbardziej powierzchowna i nie tylko analiza socjologiczna, lecz także świadomość potoczna, a nawet sami twórcy prawa zdawali sobie $\mathrm{z}$ tego sprawę, że tytuły prawne są często fikcją. Ogólniejszą wersją tego poglądu jest dominujące w prawoznawstwie i filozofii prawa stanowisko, że własność jako zjawisko nie może istnieć bez prawa jako systemu norm, co implikuje tezę, iż w epoce przedprawnej stosunki własności nie istniały ${ }^{1}$. Druga forma, jaka przybiera koncepcja prawnicza, jest określenie warunków, w których można uznać kogoś za właściciela, czyli treści stosunku własności. W Instytucjach Justyniana własność definiowana jest jako pełne władztwo nad rzeczą (plena in re potestas), które obejmowało prawo do jej posiadania, używania, pobierania pożytków i dysponowania z wyłączeniem osób trzecich ${ }^{2}$. Niewiele różnią się od niej współczesne ujęcia własności. W polskim Kodeksie cywilnym nie ma wprawdzie formalnej definicji własności, uprawnienia właściciela ujęte są jednak podobnie: obejmuja korzystanie $\mathrm{z}$ rzeczy wraz z pobieraniem $\mathrm{z}$ niej pożytków i dochodów oraz rozporządzanie nią ${ }^{3}$. Definicji własności nie znajdujemy też w niemieckim Burgerliche Gesetzbuch, który ogranicza się do wyliczenia uprawnień właściciela. Jako obiekt własności rozróżnia rzeczy (Sachen) i zwierzęta (Tiere). „Właściciel rzeczy może, o ile nie narusza ustaw lub praw osób trzecich, postępować z rzeczą w sposób dowolny i wykluczać wszelką interwencję innych. Właściciel zwierzęcia musi przez realizacji swoich prerogatyw uwzględniać szczególne przepisy służące ochronie zwierząt"4.

${ }^{1}$ Por. J. Oniszczuk, Niektóre filozoficzne uzasadnienia i krytyki instytucji własności, w: J. Jabłońska-Bońca (red.), Wtasność, Warszawa 2009, s. 79-80.

${ }^{2}$ Por. Prawo rzymskie. Stownik encyklopedyczny, red. W. Wołodkiewicz, Warszawa 1986, s. 51.

${ }^{3}$ Por. Kodeks cywilny, dział II, art. 140, Warszawa 2013, s. 48.

${ }^{4}$ Das Bürgerliche Gesetzbuch, ks. III: Prawo rzeczowe, rozdz. 3: Własność, tytuł 1: Treść własności, par. 903: Uprawnienia właściciela, http://dejure.org/gesetze/0BGB010102. 
Obowiązujący do dzisiaj we Francji Kodeks Napoleona z 1804 r. definiuje własność jako prawo korzystania i dysponowania rzeczami (choses) w sposób najpełniejszy, pod warunkiem że nie używa się go w sposób zabroniony przez prawo lub inne uregulowania ${ }^{5}$.

Definicji własności jako wielowymiarowej władzy nad rzeczą odpowiada najbardziej własność obiektów, nad którymi właściciel może fizycznie panować: działki ziemi, narzędzia, przedmiotu osobistego użytku. Napotyka ona natomiast tym większe trudności, w im większym stopniu uprawnienia owe rozdzielone są pomiędzy różne osoby. Stanisław Kozyr-Kowalski wyodrębnia w prawniczych definicjach własności dwa aspekty: dominacyjny - polegający na władzy nad rzeczą, możliwości dowolnego nią dysponowania, określania, czy, jak i przez kogo będzie używana, a nawet jej zniszczenia, oraz beneficyjny odnoszący się do użycia rzeczy i ciagnięcia z niej korzyści. Ten ostatni jest jednak podporządkowany aspektowi dominacyjnemu i najczęściej ujmowany jako szczególna postać władzy nad obiektem (utożsamianym z rzeczą) ${ }^{6}$.

Drugą charakterystyczną cechą prawniczej koncepcji własności jest pojęcie osoby prawnej jako właściciela. Poza realnymi jednostkami i grupami jednostek (spółkami) prawo uznaje za osoby także związki i instytucje (,korporacje”), jako swoistą kategorię podmiotów niezależnych od wchodzących w ich skład jednostek. Jak pisał Ulpian: „Co należy się korporacji nie należy się jej poszczególnym członkom, ani też poszczególni członkowie nie są zobowiązani do tego, do czego jest zobowiązana korporacja"7. Osobami takimi sa np.: przedsiębiorstwo, spółdzielnia, Kościół, stowarzyszenie, fundacja, państwo. Mają one w prawie status zbliżony do osób fizycznych: mogą zawierać umowy, nabywać i sprzedawać majątek, wprowadzać wśród swoich członków zmiany organizacyjne itp.

Socjologia od samych swoich początków kwestionowała leżące u jego podstaw założenia. Już Auguste Comte i Herbert Spencer, twórcy pierwszych systemów socjologicznych, krytykowali abstrakcyjny i metafizyczny charakter myśli prawniczej. Comte krytykował przede wszystkim właściwe prawu ugruntowanie ogólnego pojęcia własności na modelu własności prywatnej. Wyraża się ono w formule o prawie właściciela do używania i nadużywania jej obiektów, co jest - zdaniem Comte'a - „niesprawiedliwe i nierealne”, jako że swoboda właściciela zakłada milcząca aprobatę społeczności, do której on należy ${ }^{8}$. Spencer odróżnia własność nominalną od własności wyważającej się w realnym korzystaniu z należących do niej zasobów ${ }^{9}$. Rozszerza i różnicuje zarazem pojęcie rzeczy, zastępując je pojęciem obiektów, które dzieli na korporalne i niekorporalne. Wśród tych ostatnich wyróżnia takie, które ucieleśnione są w literaturze, muzyce i plastyce, oraz takie, które mają postać wynalazków ${ }^{10}$.

\footnotetext{
${ }^{5}$ Code civil, ks. II: O dobrach i różnych ograniczeniach własności, tytuł II: O własności. http://codes-et-lois.fr/code-civil/texte-integral.

${ }^{6}$ Por. S. Kozyr-Kowalski, Socjologia, spoteczeństwo obywatelskie i państwo, Poznań 1999, s. 101-102.

${ }^{7}$ Za: K. Kolańczyk, Prawo rzymskie, Warszawa 1973, s. 174.

8 Por. A. Comte, O wtasności, w: B. Skarga, Comte, Warszawa 1977, s. 225.

${ }^{9}$ Por. H. Spencer, The Principles of Ethics, t. 2, Indianapolis 1978, s. 116.

${ }^{10}$ Por. ibidem, s. 121-122.
} 
Szczególnie obszerną i wielostronną krytykę prawniczych ujęć własności znajdujemy u Karola Marksa i Maxa Webera. Marks za fundamentalne rozróżnienie w obrębie stosunków własności uznaje jej podział na własność ekonomiczną i pozaekonomiczną. Dokonuje tym samym podziału zarówno podmiotów, przedmiotów, jak i cech relacji pomiędzy nimi ze względu na odmienne funkcje społeczne. Przedmiotami własności ekonomicznej są środki produkcji, cyrkulacji i usług oraz siła robocza użyta do ich uruchamiania, podmiotami - jednostki lub grupy czerpiące korzyści z tych procesów. Ogólne pojęcie rzeczy i osoby ulega tu zatem destrukcji, nie każda rzecz wchodzi w zakres tego stosunku i nie każda osoba może być realnie lub nawet potencjalnie właścicielem. Odrzucone zostaje też pojęcie wszechwładzy nad rzeczą: treścią własności jest korzystanie ze środków produkcji lub siły roboczej w celu zdobycia (niezbędnych lub luksusowych) środków utrzymania ${ }^{11}$. Weber, idąc w tym za Marksem, także wyraźnie wyodrębnia własność ekonomiczną, której obiektami sa rzeczowe środki produkcji, praca wykonawcza i praca dyspozycyjna, a treścią ich apropriacja, czyli szanse monopolistycznego użytkowania. Szczególnie ostro krytykuje Weber przenoszenie na poziom analizy socjologicznej koncepcji osoby prawnej, widząc w jej konstrukcji niedopuszczalny na gruncie nauk empirycznych realizm pojęciowy. Fikcyjne podmioty społeczne, mające uzasadnienie teoretyczne w prawoznawstwie jako nieempirycznej dyscyplinie nauki, muszą na gruncie socjologii zostać zastąpione podmiotami realnymi (jednostkami lub grupami jednostek) ${ }^{12}$.

Podstawowe socjologiczne argumenty przeciwko ujęciu prawniczemu zebrał i usystematyzował wspomniany już Kozyr-Kowalski, który rozwiną także własną - w mojej opinii we współczesnej socjologii najciekawszą - teorię własności ${ }^{13}$. Pierwszym, odwołującym się do długiej tradycji socjologicznej założeniem tej koncepcji jest uznanie za podmioty własności wyłącznie jednostek lub grup jednostek. Oznacza to odrzucenie pojęcia osoby prawnej i konieczność ustalenia, jaka „fizyczna” osoba lub osoby stoją w konkretnym wypadku za tego rodzaju fikcjami prawniczymi. Poza przytoczonymi wyżej argumentami Webera przesłanką odrzucenia pojęcia osoby prawnej jest jej socjologiczna nieokreśloność. Za pojęciem własności przedsiębiorstwa, stowarzyszenia lub państwa kryć się mogą różne, często wręcz wykluczające się stosunki realnego użytkowania i korzystania: wspólna własność wszystkich uczestniczących w nich osób, własność pewnej grupy takowych, własność jednej z nich, własność jednostki lub grupy spoza tych instytucji. Po drugie, dokonuje ona destrukcji właściwego prawu pojęcia rzeczy - wyraźnie różnicuje obiekty

11 Obszerną analizę teorii własności ekonomicznej Marksa znaleźć można w rozprawie: S. Kozyr-Kowalski, Wtasność jako zjawisko ekonomiczno-spoteczne w świetle badań Karola Marksa i Maxa Webera; idem (red.), Wtasność: gospodarka a prawo. Studia o marksistowskiej teorii wtasności, Warszawa 1977, s. 72-122).

${ }^{12}$ Por. M. Weber, Gospodarka i społeczeństwo. Zarys socjologii rozumiejacej, Warszawa 2002, s. 32-34 i 93-105. Por także S. Kozyr-Kowalski, Wtasność jako zjawisko ekonomiczno-społeczne..., s. 47-72.

${ }^{13}$ Najpierw w artykule Wtasność jako zjawisko ekonomiczno-spoteczne w świetle badań Karola Marksa i Maxa Webera z 1977 r. (op. cit). Jej najbardziej rozwiniętą postać zawiera jego książka Socjologia..., rozdz. 2-4. Zmodyfikowaną wersję tej teorii znaleźć można także w pracach Jacka Tittenbruna, który nazywa ją rentową teorią własności (por. J. Tittenbrun, Gospodarka w spoteczeństwie, Poznań 2012, rozdz. I.11). 
własności odpowiednio do ich cech (rzeczy, ale także procesy materialne, zwierzęta, cechy cielesne i umysłowe ludzi, obiekty idealne). Różnicuje ona także pojęcie przedmiotu własności - odnosi się wprost do tradycji marksistowskiej (mającej jednak także swoje odpowiedniki w klasycznej i współczesnej socjologii) - na obiekty o charakterze ekonomicznym (środki produkcji, wymiany i usług oraz odpowiednie typy siły roboczej) oraz obiekty pozaekonomiczne. Podział ten oznacza odrzucenie zawartego w teorii prawniczej formalistycznego założenia zapoznającego odmienność funkcji rzeczy w życiu społecznym. Fundamentalną tezą tej koncepcji, będąca najbardziej oryginalnym jej składnikiem, jest uznanie za sens pojęcia własności obiektu gratisowego korzystania z niego. Oznacza to - po pierwsze - abstrahowanie od posiadania lub nie tytułu właściciela, po drugie - odrzucenie właściwego prawu dominacyjnego ujęcia tego stosunku. W wypadku obiektów trwałego użytku brak ekwiwalentu w czystej postaci oznaczać może bądź istnienie procesu samodzielnej regeneracji ich zużytych elementów, bądź odtwarzanie ich przez innych. Za stosunek korzystania bez ekwiwalentu uznać jednak można także sytuację odtwarzania zużytych elementów obiektu przez samego właściciela (czyszczenie przedmiotów, ich reperacja, konserwacja itp.). W wypadku środków produkcji gratisowość korzystania dotyczy wykorzystywanych za ich pomocą obiektów i sił przyrody oraz dorobku duchowego minionych pokoleń (nauka).

W najogólniejszym ujęciu zróżnicowanie podmiotów własności na indywidualne i kolektywne pozwala podzielić własność na indywidualna i wspólną. Zastosowanie pozostałych kryteriów modyfikuje jednak dość istotnie ten podział. Rozróżnimy tu własność ekonomiczną i pozaekonomiczną. Odniesienie własności indywidualnej do różnic funkcji społecznych pozwala podzielić ja na własność przynoszącą dochody (ekonomiczna własność prywatna) i własność niepełniącą tej funkcji (nieekonomiczna własność osobista). Natomiast własność przynoszących dochód obiektów uruchamianych zbiorowa praca samych właścicieli nosić będzie miano ekonomicznej własności wspólnej: grupowej (spółdzielczość) lub ogólnospołecznej. W tym ostatnim wypadku do kategorii współwłaścicieli zaliczać będziemy także osoby jeszcze niepracujące (uczniów, dzieci) oraz już niepracujące (emerytów). Istnieje wreszcie nieekonomiczna własność grupowa lub ogólnospołeczna, obejmująca obiekty konsumpcji materialnej lub duchowej: publiczne parki, ulice, drogi bite, środki transportu, obiekty kultury i rozrywki, obiekty i środki kultu religijnego itd.

Teoria własności wspólnej była w historii refleksji socjologicznej nad problematyką własności najsłabiej opracowanym jej działem. Własność prywatna ujmowana była najczęściej bądź jako model własności wspólnej, bądź nawet uznawana za synonim własności w ogóle. Aspekt ten wyraża pojęcie wykluczania innych. Gdy nie ma wykluczania - nie ma własności. Jak pisze Richard Pipes, stosunek własności wymaga uświadomienia sobie relacji do obiektu, a to zakłada, że obiekt jest przedmiotem pożądania i występuje w ograniczonej ilości ${ }^{14}$. To właśnie jest założenie wywodzące się z modelu własności prywatnej. Własność wspólna może, ale nie musi zakładać ograniczoności zasobów, co

${ }^{14}$ Por. R. Pipes, Wtasność a wolność, Warszawa 2000, s. 128. 
eliminuje zjawisko wykluczania. Także charakteryzowana wyżej koncepcja, leżąca u podstaw podjętej $\mathrm{w}$ artykule próby analizy własności komunalnej, zawiera wiele kwestii nierozwiązanych, a i niniejszy artykuł nie pretenduje do wypełnienia tego zadania. Przed bezpośrednim zmierzeniem się z tą problematyka prezentuje on dwie wybrane próby jej socjoekonomicznego i socjologicznego ujęcia.

\section{WŁASNOŚĆ WSPÓLNOTOWA I WŁASNOŚĆ PUBLICZNA W UJĘCIU TEORII PRAW WŁASNOŚCI}

Współcześnie najciekawszym i najbardziej teoretycznie zaawansowanym kierunkiem badań nad własnościa w naukach społecznych na Zachodzie jest teoria praw własności (property rights), która obecnie wydaje się paradygmatem dominującym w ekonomicznej analizie tej sfery zjawisk. Jest to teoria ekonomiczna, ale jako że programowo próbuje ona uwzględniać pozaekonomiczne aspekty tego zjawiska, można uznać ją za pokrewną analizom socjologicznym. Jej przedstawiciele, spośród których najważniejszymi są Armen Alchian, Yoran Barzel, Svetozar Pejovich, Ronald Coase, Harold Demsetz, Daniel Bromley, Steven N. S. Cheung, próbuja przełamać pewne aspekty prawniczej koncepcji własności dzięki uwzględnieniu relacji pomiędzy jej kategoriami a pojęciami ekonomicznymi, choć nie są w stanie uwolnić się od niej pod wieloma innymi względami.

W sferze założeń pozostaja oni $\mathrm{w}$ pełni zgodni z koncepcja prawniczą. Podobnie jak ona czynią oni własność prywatną ogólnym modelem własności, ujmując ja jako stosunek osoby do zasobu. Własność to prawo do zasobu, co oznacza wszelką decyzję dotycząca użycia zasobu. Przez zasób, którym to pojęciem zastępują oni pojęcie rzeczy, rozumieja poza obiektami materialnymi także własne ciało i umysł (poruszanie się, mówienie). Użycie zasobu jest pojęciem bardzo szerokim, oznacza nie tylko posłużenie się nim jako środkiem, lecz także przesunięcie go $\mathrm{w}$ przestrzeni, modyfikację (np. przycięcie gałęzi drzewa), pokrycie go farbą itp. Jak widać, są to tylko sformułowane za pomoca nieco innych kategorii podstawowe tezy koncepcji prawnej. Prawniczą genezę i sens ma także pojęcie publicznych praw własności, których podmiotem jest państwo. Oryginalność tej koncepcji na tle innych polega - po pierwsze - na zdefiniowaniu trzech modeli praw własności (prywatne, wspólnotowe i publiczne) i obiektywnej, tzn. możliwej do skonfrontowania z faktami analizie porównawczej ich konsekwencji ekonomicznych i społecznych; po drugie - powiązanie pojęcia praw własności ze zjawiskami będącymi ich konsekwencjami lub warunkami, takimi jak: koszty, ryzyko, odpowiedzialność, wiedza niezbędna do podejmowania decyzji itp.

Własność prywatna (prywatne prawo własności) oznacza, że jedna osoba podejmuje wobec zasobu decyzje w nieograniczonym zakresie, tj. we wszystkich aspektach. „Te dwa składniki: a) nieograniczony zakres i b) jednoosobowy proces decyzji charakteryzują prawo własności" ${ }^{15}$. Naruszenie tej relacji w obu

${ }^{15}$ A. Alchian, Some Implications of Recognition of Property Right Transactions Costs, w: S. Pejovich (red.), The Economic Foundation of Property Rights, Cheltenham-Lyme 1997, s. 13. 
aspektach prowadzi do zmiany charakteru własności na kolektywny. W aspekcie decyzyjnym tworzą się wówczas różne kategorie własności prywatnej. „Gdy decyzje są dzielone (wspólne), własność może być korporacyjna (corporate) lub partnerska, choć ciagle określać się ją będzie jako "prywatną «"16. Ograniczenie zakresu decyzji właściciela jest mniej jednoznaczne. „W prawie osoby do zasobu zawiera się prawdopodobieństwo, że jej decyzja dotycząca określonych użytków danego zasobu będzie określała taki użytek w tym sensie, że dominuje nad decyzja jakiejkolwiek innej osoby" ${ }^{17}$.

Teoretycy praw własności podkreślaja wielokrotnie, że własność nie jest stosunkiem ludzi do rzeczy, lecz stosunkiem społecznym, tzn. stosunkiem pomiędzy ludźmi wyznaczonym przez rzeczy. Zdaniem Richarda McKenziego i Gordona Tullocka: „Prawa własności dotyczą dopuszczalnego użycia zasobów, dóbr i usług. Definiuja one granice zachowań społecznych, a tym sposobem określają także to, co jednostki moga robić w społeczeństwie. [...] Prawa własności sa zjawiskiem społecznym, wyrastają z konieczności współżycia jednostek pomiędzy sobą w przestrzeni społecznej, w której wszystkie one chca poruszać się i wchodzić w interakcje" ${ }^{18}$.

Przez prawa własności rozumie się więc reguły wzajemnych oddziaływań pomiędzy ludźmi, normy nadające jednostkom uprawnienia i obowiązki, które sa zapośredniczone przez zasoby. Te zasoby to przede wszystkim rzeczy i inne obiekty materialne, ale także dobra niematerialne, ciała ludzkie oraz zdolności psychiczne i intelektualne. Przy tak szerokim rozumieniu tego pojęcia można wszelkie reguły życia społecznego zdefiniować w kategoriach praw własności. Teoria praw własności staje się tu ogólną teorią struktury społecznej, teorią socjologiczną, własność traci swój ekonomiczny wymiar i oznacza wszelkie relacje współdziałania i wykluczania społecznego. Rzeczy interesuja nas tu tylko o tyle, o ile współwyznaczają relację pomiędzy ludźmi. Jak piszą wspomniani wyżej autorzy: „A więc prawa własności moga być ujęte w kategoriach reguł zachowania, które skutecznie ograniczaja i określają nasze zachowanie" ${ }^{19}$. Dalej zaś jeszcze dobitniej: ,Taka jest podstawa reguł zachowania lub, co na jedno wychodzi, praw własności” ${ }^{20}$. Pozwala to zrozumieć, dlaczego pojęcie własności jako stosunku społecznego zastąpione zostaje pojęciem praw własności, czyli zasad regulujących zakres dostępu poszczególnych jednostek do zasobów. Wyraziście ilustruje to przytoczony przez McKenziego i Tulocka przykład Robinsona Crusoe. Zanim nie spotkał on Piętaszka, pojęcie własności w ogóle nie miało zastosowania do jego relacji z zasobami przyrody i przedmiotami zabranymi z rozbitego statku, choć używał tych obiektów. Ustalenie reguł wzajemnych stosunków pomiędzy nimi było równoznaczne ze zdefiniowaniem praw własności ${ }^{21}$.

${ }^{16}$ Ibidem.

17 Ibidem.

${ }^{18}$ R. B. McKenzie, G. Tullock, Modern Political Economy. An Introduction to Economics, New York 1978, s. 77.

19 Ibidem, s. 78.

20 Ibidem.

${ }^{21}$ Por. ibidem, s. 77. 
Robinson wraz z Piętaszkiem tworzyli pewien zespół, w którym prawa własności były podzielone. Nie musi to jednak być konieczne w wypadku ich niezależności. Gdyby na wyspie poza Robinsonem Crusoe znalazł się także inny osobnik, który na własną rękę korzystałby z zasobów przyrody wyspy, to ciągle nie istniałyby tam jasno zdefiniowane prawa własności, tzn. nie byłoby tam żadnych wspólnych reguł zachowań określających ich sfery interesów. Zasoby wyspy byłyby własnością wspólnotową (communal property). Svetozar Pejovich charakteryzuje ją następująco. „Własność wspólnotowa oznacza, że precyzyjnie określona grupa ludzi ma łącznie obiekt nieprzekazywalny. Zwykle członkowie grupy maja prawo decyzji co do użytkowania obiektu, z którego wynika prawo do alokacji, ale nie moga sprzedać tych praw innym. Prawa te nabywaja oni wraz z wstapieniem do grupy, a traca je wraz z jej opuszczeniem" ${ }^{22}$.

Ten model własności (wspólnotowe prawa własności) zakłada, że członkowie owej grupy używają danego zasobu niezależnie od siebie. Każdy z użytkowników ponosi indywidualnie zróżnicowane koszty (koszty prywatne) niezbędne do podjęcia decyzji dotyczącej danego zasobu i użycia go. Często przytaczanym przykładem jest tu indywidualne polowanie na bobry przez Indian amerykańskich lub wypas prywatnie posiadanego bydła na wspólnym pastwisku. Model ten funkcjonuje bez zakłóceń przynajmniej dopóty, dopóki zasoby przyrody nie stają się dobrami rzadkimi, tzn. dopóki przewyższają potrzeby, do zaspokojenia których mogą być użyte.

Sytuacja ta, będąca wynikiem wyczerpywania się zasobów bądź w wyniku ich niezdolności do odnawiania utraconych elementów, bądź zwiększenia intensywności ich użytkowania, wytwarza nową kategorię kosztów: koszty społeczne. Zwiększenie stopnia trudności lub niezbędnego czasu użytkowania zasobu (upolowania pojedynczego bobra lub wykarmienia krowy) oznacza dodatkowe koszty, które nakładaja na siebie wzajemnie współwłaściciele. Gdy koszty te są niewielkie, własność ta może funkcjonować dalej - korzyści ciągle przekraczać będą oba rodzaje kosztów. Często jednak przyczyny prowadzące do ograniczenia obfitości zasobu prowadzą do coraz systematyczniejszego jego zmniejszania, co grozi całkowita jej likwidacja, bądź - aby temu zapobiec prowadzi do przekształcenia jej w jedna $\mathrm{z}$ dwóch alternatywnych postaci: własność prywatną lub własność publiczna.

Prywatne prawa własności mogą wyrażać się w postaci podziału terenu (zasobu) na prywatne działki przydzielone poszczególnym dotychczasowym uczestnikom tego zasobu bądź wywłaszczeniu tych użytkowników i skoncentrowania wszystkich praw własności w rękach jednej lub kilku osób. Podmiotem własności prywatnej nie musi być bowiem jedna osoba, może ona być, jak się wyraża Armen Alchian, korporacyjna lub partnerska ${ }^{23}$, prywatni współwłaściciele muszą jednak mieć, na mocy wspólnej decyzji, prawo do jej sprzedania. W wypadku nabrania przez zasób charakteru własności prywatnej (jednoosobowej lub grupowej) użytkowanie go wymaga opłat na rzecz właściciela. Model prywatnych praw własności zakłada przeznaczenie opłat od

${ }^{22}$ S. Pejovich, Introduction to Chapters 2, 3, 4 and 5, w: S. Pejovich (red.), op. cit., s. 4.

${ }^{23}$ Por. A. Alchian, op. cit., s. 13. 
użytkowników bądź na ograniczenie nadmiernego użycia zasobu, bądź na odtworzenie elementów zużytych oraz zawiera także zysk właściciela. Koszty prywatne użytkowników znacznie wzrastają, znika też występujący poprzednio koszt społeczny. Powstać jednak może nowy typ kosztu społecznego, wtedy gdy funkcjonowanie objętego prywatnymi prawami własności zasobu wytwarza negatywne konsekwencje dla działalności osób trzecich. Chodzi o koszty wytworzone przez właścicieli, które ponosić muszą niewłaściciele (np. koszty zatrucia środowiska przez przemysł). Jeżeli właściciel pokrywa spowodowane przez niego koszty dla innych, stają się one jego kosztami prywatnymi. Jeżeli nie - a często, jak np. w wypadku zatrucia środowiska, nie jest to w pełni możliwe - stają się one kosztami społecznymi.

Wspólną cechą modelu publicznych praw własności i modelu wspólnotowych praw własności jest niemożność sprzedaży posiadanych dóbr. Ten pierwszy oznacza jednak ustanowienie reguł użytkowania zasobu i ściągania opłat oraz administrowania nimi w celu jego utrzymania, względnie powiększenia. Wymaga to powołania zespołu administrującego, którego utrzymanie pochłania część opłat pochodzących od użytkowników. Reprezentuje on schemat działalności non profit, tzn. dochody nie przewyższają kosztów, a ewentualne zyski przekazywane są na rzecz powiększenia majątku lub ułatwienia dostępu do niego członkom grupy. Inaczej mówiąc, nie generuje on prywatnych zysków. Obiektem badań teoretyków praw własności sa często różnice pomiędzy własnością prywatną a publiczną zarówno w aspekcie wytwarzanych przez nie strat, jak i korzyści. Jak to ujmują McKenzie i Tullock „,W przypadku własności prywatnej i przy braku konkurencji właściciele moga usiłować pobrać opłaty wyższe niż koszt społeczny. [...] Z drugiej strony także podatki nałożone przez państwo mogą być większe niż koszt społeczny. Państwo także może działać jak monopolista. Agencje państwowe nie przynoszą być może »zysków «, tak jak to się normalnie rozumie, ale to nie eliminuje użycia osiąganych przez nie dochodów do podwyższania swoich pensji i polepszania warunków pracy pracownikom państwowym [...]. Własność państwowa niekoniecznie prowadzi do marnotrawstwa, ale tylko naiwni zignorowaliby zagrożenie idące $\mathrm{w}$ tym kierunku" ${ }^{24}$. Alchian wylicza także inne względy, pod którymi prywatne prawa własności górują nad publicznymi (efektywność, zdolność ponoszenia ryzyka, uwzględnianie przyszłych konsekwencji decyzji, związek wysiłku indywidualnego z wynikami ekonomicznymi itd. $)^{25}$.

Pojęcie publicznych praw własności różni się od praw wspólnotowych pod jeszcze innym względem. To ostatnie rozumiane jest jako należące do grupy ludzi, jako własność wspólna. Tymczasem za podmiot publicznych praw własności uznaje się państwo. Pojęcie to nie podlega już najczęściej dalszemu rozbiorowi. Jedną z prób jego interpretacji podejmuje Pejovich, uznając, że za pojęciem państwa jako właściciela faktycznie stoja jego funkcjonariusze. „Jednakże termin własność państwowa jest tylko fasada słowna, ukrywająca prawdziwego właściciela, którym jest elita polityczna" ${ }^{26}$. Przesłanką tej tezy jest

\footnotetext{
${ }^{24}$ R. B. McKenzie, G. Tullock, op. cit., s. 86.

${ }^{25}$ Por. A. Alchian, op. cit., s. 11-19.

${ }^{26}$ S. Pejovich, Introduction to Chapters 2, 3, 4 and 5, op. cit. s. 4.
} 
uznanie decydowania za główne kryterium własności. Inny nurt teorii praw własności wydaje się uznawać istnienie sfery autonomicznych decyzji publicznych nie za wyraz współwłasności zarządzanych zasobów przez sztab administracyjny (wyrażenie Webera), lecz za przesłankę powszechnego użytkowania tych zasobów. Mogłoby to prowadzić do traktowania decyzji elity administracyjnej dotyczących użytkowania własności państwowej jako artykulacji interesów i potrzeb jej rzeczywistych użytkowników. Tak czy owak, pojęcie państwa i własności państwowej jest jednym ze zdecydowanie słabych punktów teorii praw własności.

Jak piszą McKenzie i Tullock, poza przekształceniem wspólnotowych praw własności w prawa publiczne istnieją dwa inne sposoby internalizacji kosztów społecznych (jak nazywa się zjawisko ich pokrywania): przez prywatyzację tych praw oraz przez „,wzgląd na innych” i ,odpowiedzialność za koszty społeczne” ze strony samych zainteresowanych (współwłaścicieli) ${ }^{27}$. Przykładem takiego mechanizmu jest funkcjonowanie rodziny. Praktycznie w sytuacji ograniczonej, lecz zapewniającej pokrycie potrzeb wielkości zasobu oznacza to staranność i powstrzymanie się od marnotrawstwa w korzystaniu z niego, w wypadku zaś niedoboru zasobu wymagane może być świadome ograniczenie potrzeb. Możliwość istnienia takiego układu stosunków własności prowadzi do wyodrębnienia czwartego, nieuwzględnionego przez tych autorów modelu, który można by nazwać publiczno-wspólnym. Różnica w stosunku do modelu wspólnych praw własności polega na uchyleniu założenia o niezależności poszczególnych użytkowników, co ma właśnie miejsce w wypadku rodziny. Zasób używany jest swobodnie według potrzeb dopóty, dopóki istnieje on w nadmiarze, w sposób umiarkowany i uwzględniający koszty społeczne zaś wówczas, gdy nabiera cech zasobu rzadkiego. Przesłanką takiej formy internalizacji kosztów społecznych jest w tym wypadku wspólny dla użytkowników zespół wartości i norm kulturowych obowiązujących ich jako członków wspólnoty (co zakałada własność komunalna), norm odnoszących się także do sposobu użytkowania zasobów wspólnych (a więc analogicznych do publicznych praw własności). Różnica w stosunku do modelu zakładającego ,,wzgląd na innych” polegałaby na normatywnym, a nie psychologicznym charakterze tych ograniczeń. Różnica w stosunku do modelu własności publicznej - na pozaprawnym charakterze regulujących te ograniczenia norm.

Przewaga tej lub innej formy praw własności pod określonym względem nie zawsze rozstrzyga jeszcze sama $\mathrm{w}$ sobie o jej wyższości praktycznej. Przekształcenie jednej formy w inną pociąga bowiem za sobą koszty, zwane kosztami transakcyjnymi, które moga wyrównywać, a nawet przewyższać oczekiwane korzyści. Koszty transakcyjne to koszty wszystkich zasobów niezbędnych do dokonania transferu własności. Według Olivera Williamsona składają się na nie koszty ex ante (projektowanie transakcji, negocjowanie i ochrona) oraz koszty ex post (niedoskonała adaptacja jako rezultat luk, błędów, pominięć i nieprzewidzianych zakłóceń oraz utrzymanie systemu ekonomicznego ${ }^{28}$.

${ }^{27}$ Por. R. B. McKenzie, G. Tullock, op. cit., s. 86.

${ }^{28}$ Por. O. Williamson, Transaction Costs Economics and Organization Theory, w: N. J. Smelser, R. Swedberg (red.), The Handbook of Economic Sociology, Princeton-New York 1994, s. 103. 
Różnice i wzajemne relacje pomiędzy własnością wspólnotową, publiczną i prywatną dobrze oddaja przykłady zaczerpnięte z pism teoretyków tej szkoły ${ }^{29}$.

Zanieczyszczenie środowiska

W warunkach wspólnotowych praw własności, w których nie ma nadrzędnego ośrodka kontrolnego, koszt społeczny, jaki stanowi zanieczyszczenie środowiska, ponoszą bądź sami jego wytwórcy, bądź (także) inni, którzy ze względów na bliskość przestrzenną ponoszą w ich wyniku straty (choroby, usuwanie zanieczyszczeń).

Współcześnie takie zasoby, jak: rzeki, strumienie, powietrze, są obiektem publicznych praw własności. Są one przedmiotem wspólnego użycia i nadużycia. Nie usuwając jednak tych zanieczyszczeń ani nie rekompensując kosztów ich usuwania tym, którzy ponoszą z tego tytułu szkody, wytwarzaja koszty społeczne internalizowane przez państwo, bądź z podatków płaconych przez wszystkich ( $\mathrm{w}$ większości przez tych, którzy nie wytwarzają zanieczyszczeń, w tym także tych, którzy z ich powodu ponoszą straty).

\section{Handel futrami bobrów}

Pierwotne tereny łowieckie plemion Indian amerykańskich były obiektem wspólnotowych praw własności. Zasoby przyrodnicze istniały w obfitości, a ich ubytki były w sposób naturalny rekompensowane. Sytuacja zmieniła się zasadniczo wraz z pojawieniem się i rozwojem handlu skórami, prowadzonego przez białych kupców. Popyt i tym samym cena skór wzrosły, co znacznie zwiększyło liczbę zabijanych zwierząt. Powstał tym samym koszt społeczny, który każdy myśliwy, intensyfikując swoją aktywność łowiecka, nakładał na wszystkich innych myśliwych. Ponieważ zakłada się tu, że myśliwi byli od siebie niezależni, nie mieli powodów, aby chronić stan fauny, gdyż nie mieli żadnej gwarancji, że podobnie postapia inni. Rozwiązaniem problemu nadmiernego wybijania zwierząt stał się podział terenów łowieckich na prywatne działki. Niezależne od poszczególnych myśliwych koszty społeczne zniknęły, a oni sami, aby utrzymać stan liczebny zwierząt na swoim terenie, zmuszeni byli ograniczyć polowania.

\section{Polowanie na wieloryby}

Morza i oceany oraz żyjące w nich wieloryby i foki były i są objęte prawami własności wspólnotowej i od setek lat były też celem polowań. Mniej więcej dwieście lat temu pojawił się problem z ich reprodukcją, w XX w. zaś z powodu udoskonalenia technologii umożliwiającej zabijanie i oprawienie ich na pełnym morzu - problem wytępienia tego gatunku. Pomimo tego zagrożenia stosunki własności nie mogą tu ulec zmianie ze względów technicznych. Oddanie określonych obszarów morskich na własność prywatną nie rozwiązuje

\footnotetext{
${ }^{29}$ Por. R. B. McKenzie, G. Tullock, op. cit.; J. P. Beckwith, Jr., Parks, Property Rights, and the Possibilities of the Private Law, „Cato Journal” 1, 1981, nr 2 (Autumn); R. J. Smith, Resolving the Tragedy of the Commons by Creating Property Rights in Wildlife, „Cato Journal” 1, 1981, nr 2 (Autumn).
} 
problemu, gdyż wieloryby przemieszczaja się - przemierzaja rocznie do 10 tys. km. Musiałaby tu wchodzić w gree prywatyzacja całych mórz lub oceanów, co jest praktycznie niemożliwe zarówno ze względów ekonomicznych, jak i politycznych.

Autostrady

Autostrady bezpłatne stanowią rodzaj zasobu będącego dla ich użytkowników obiektem własności wspólnej. Użytkowanie autostrad wytwarza wprawdzie koszt społeczny w postaci technicznego zużycia elementów drogi, a także zanieczyszczenia środowiska i innych niedogodności dla mieszkańców pobliskich terenów, ale koszty te pokrywane są przez państwo. Środkiem umożliwiającym tę ,internalizację kosztów społecznych” sa podatki ogólne. Jeżeli jednak państwo pobiera te środki od samych kierowców (opłaty rogatkowe i podatek od paliwa), prawa własności wspólnotowej przekształcone zostają w publiczne prawa własności.

Kosiarki, narzędzia i nasiona ogrodowe

$\mathrm{W}$ jednym $\mathrm{z}$ miast $\mathrm{w}$ Virginii istnieje wyodrębniony rejon budownictwa mieszkalnego, na którym poszczególne domy są własnością prywatną, natomiast teren jest wspólną własnością wszystkich mieszkańców. Aby zagwarantować odpowiedni poziom utrzymania terenu, inwestorzy uczynili warunkiem zakupu domu członkostwo w stowarzyszeniu mieszkańców, wymagające opłacania składki przeznaczonej na ten właśnie cel. Oprócz terenów wspólnych do każdego domu przylega też niewielka działka będącą prywatną własnością właściciela domu. Aby ułatwić uprawę i utrzymanie tych działek, stowarzyszenie dostarczyło ich posiadaczom kosiarki do trawy, narzędzia ogrodnicze i nasiona trawy, zmagazynowane w ogólnie dostępnej dla każdego z nich szopie. Kierowano się tu oszczędnością - indywidualna własność kosiarki, narzędzi i trawy oznaczałaby ich nikłe wykorzystanie ze względu na niewielkie rozmiary działek. Użytkowano te zasoby zatem odpowiednio do potrzeb. Mimo że utrzymanie porządku na osiedlu, przeprowadzane przez wynajęte firmy, funkcjonowało właściwie, to zasady użytkowania przyrządów ogrodniczych nie sprawdziły się. Już po roku kosiarki rozpadły się z powodu niedbałości, narzędzia poznikały, a ilość zużytej trawy kilkukrotnie przekroczyła potrzeby wyznaczone obszarem działek.

McKenzie i Tullock nazywają obie formy własnością wspólnotową (communal). W porównaniu z poprzednimi przykładami tego typu własności brakuje im jednak cechy niezbywalności, zgodnie z definicja Pejovicha byłyby one zatem formami prywatnych praw własności. Ponadto cechy własności wspólnotowej posiada tylko własność narzędzi: ich swobodne użytkowanie wytwarzające koszt społeczny przypomina polowanie na wieloryby. Natomiast tereny zielone osiedla objęte sa prawami analogicznymi do własności publicznej: koszt społeczny jest internalizowany przez ,,podatek” płacony stowarzyszeniu. Tak czy owak, formy te należy odróżnić od dotychczas omawianych przykładów własności prywatnej i wspólnotowej i uznać bądź za swoiste postacie 
prywatnych praw własności, bądź za swoiste postacie wspólnotowych i publicznych praw własności. Możliwość bądź niemożliwość sprzedaży wyraża bowiem ich związek z rynkiem i uzależnienie od niego, czyli ich odmienne miejsce w globalnej strukturze gospodarczej.

Przytoczone wyżej przykłady pozwalają dostrzec, że zarówno własność wspólna, jak i własność prywatna pozostają w ujęciu szkoły praw własności na poziomie zbyt abstrakcyjnym. Za prywatyzację własności wspólnej uznaje ona fakt formalnego przekazania lub sprzedania jej prywatnemu właścicielowi, podczas gdy wykorzystywanie jej do celów zarobkowych jest jej faktyczna prywatyzacją, niezależną od formalnych praw własności, którą trzeba odróżnić od korzystania z niej do celów konsumpcyjnych, co nie pozbawia jej cechy wspólności. Podobnie zanieczyszczanie środowiska przez prywatny przemysł, którego koszty oczyszczania ponosi państwo, także oznacza faktyczną prywatyzację pewnej części tego środowiska. Pewną formą wyłączania części zasobów z puli własności wspólnotowej lub publicznej jest monopolizowanie jej przez mniejszą wspólnotę. Gdy przeznaczana jest na cele konsumpcyjne, staje się ona wtedy własnością wspólnotową lub publiczną o mniejszym zasięgu.

\section{KONCEPCJA WŁASNOŚCI GMINNEJ FLORIANA ZNANIECKIEGO}

Koncepcję własności rozwinął Florian Znaniecki w trakcie swoich badań nad Poznaniem w latach $1928-1931^{30}$. Analiza treści i motywów opinii mieszkańców Poznania na temat ich „,zobowiązań wobec miasta” i ocen „,doznanych z jego strony dobrodziejstw" wymagała rozwiązania kwestii własności miejskiej i jej roli w życiu mieszkańców. Znaniecki wychodzi od tezy, że elementem każdej grupy sa wartości nazwane przez niego zbiorowymi. Wartości maja charakter materialny lub duchowy. Zarówno wartości materialne, jak i duchowe są dwojakiego rodzaju: takie, z których korzystają wszyscy członkowie grupy (odpowiadaja zaspokojeniu potrzeb ogólnych), oraz przeznaczone tylko dla szczególnych jej kategorii (zaspokajające potrzeby szczególne, właściwe tylko pewnym kategoriom członków). Za specjalną kategorię potrzeb i odpowiadających im wartości uważa Znaniecki potrzeby przyszłych członków grupy.

Znaniecki rozróżnia z kolei takie typy wartości, które grupa udostępnia członkom do użytkowania (mające głównie charakter materialny), oraz takie (zarówno materialne, jak i duchowe), które dostarczane sa im w formie usług (,,świadczeniach o charakterze czynnościowym”), wykonywanych w imieniu grupy na rzecz jej członków przez powołanych przez nią funkcjonariuszy bądź wyznaczonych członków. Nie tylko usługi materialne, lecz także te o charakterze duchowym wymagają zawsze wartości materialnych jako swojego środka, a tym samym stanowią część materialnych wartości grupy ${ }^{31}$.

\footnotetext{
${ }^{30}$ F. Znaniecki, J. Ziółkowski, Czym jest dla ciebie miasto Poznań? Dwa konkursy: 1928/1964, Warszawa-Poznań 1984.

${ }^{31}$ Por. ibidem, s. 72.
} 
Funkcjonowanie pierwszej kategorii wartości różni się $\mathrm{w}$ zależności od wielkości grupy. W grupach małych ich dostępność dla ogółu członków wymaga od każdego z nich specjalnych działań w tym kierunku, które Znaniecki nazywa „przyczynianiem się" do realizacji tej dostępności. Polega ono na czynnym udziale w pracy nad ich ,utrzymaniem” oraz „,rządzeniem” nimi, w taki sposób, aby umożliwić korzystanie z niej wszystkim członkom grupy. W grupach dużych zadanie to powierzone zostaje specjalnie powołanym do tego funkcjonariuszom, działającym w imieniu i pod kontrolą członków ${ }^{32}$. Także świadczenia grupy na rzecz członków realizowane są zawsze przez specjalne kategorie funkcjonariuszy. Tę ostatnią kategorię funkcjonariuszy należy więc odróżnić od tych, którzy zarządzają i administrują wartościami grupowymi.

„W stosunku między grupa a członkiem - obowiązkiem grupy jest udostępnianie członkom korzystania $\mathrm{z}$ wartości zbiorowych. Obowiązkiem członka przyczynianie się do trwania lub odtworzenia tych wartości, których używa, gdyż jest to niezbędnym warunkiem, aby grupa mogła wykonywać nadal swój obowiązek. W grupach nowoczesnych i w odniesieniu do wartości materialnych obowiązek ten ma formę przyczynku ekonomicznego, umożliwiającego grupie utrzymanie jej własności materialnej, mimo jej zużywania przez poszczególnych członków, w takim stanie, aby mogli oni z niej dalej korzystać. Jest to powinność pozytywna. Powinność negatywna: powstrzymanie się od niszczenia wartości grupowych" ${ }^{33}$.

Stosunek między grupa a jej członkami jest więc niesymetryczny: to, co ofiaruje ona członkom, nie musi być jej przez nich zwracane. Członkowie grupy korzystaja z wartości grupowych bezpłatnie, ich obowiązkiem jest jedynie odtwarzanie tych wartości tam, gdzie rezultatem korzystania z nich jest ich zużycie. Te świadczenia odtworzeniowe, mające postać świadczeń czynnościowych lub pieniężnych, „nie stanowią - jak pisze Znaniecki - równoważnika korzyści otrzymywanych przez członka" ${ }^{34}$ od grupy. Źródłem tej niesymetryczności jest fakt, że grupa gromadzi wartości tworzone a następnie dziedziczone przez poprzednie pokolenia jej członków: „We własności gminnej zawiera się dorobek kulturalny niezliczonych jednostek żywych i umarłych, z których olbrzymia większość już nie korzysta” ${ }^{35}$. Fakt ten ,uniemożliwia równoważność tych korzyści wzajemnych" 36 .

Wartości materialne grupy nazywa Znaniecki jej własnością, egzemplifikując je w swojej analizie własnością miejską. Elementy własności miejskiej (będącej formą własności gminnej), które miasto udostępnia członkom do indywidualnego użytkowania, to ulice, place, parki, urządzenia kanalizacyjne, wodociagowe, elektryczne, tramwaje, autobusy itp. Druga kategoria tej własności są wartości materialne, będące środkami świadczeń czynnościowych (bezpieczeństwo, usługi medyczne, zapomogi pieniężne, edukacja, sztuka, biblioteki, usługi prawne, opieka nad ubogimi) ${ }^{37}$.

\footnotetext{
32 Por. ibidem.

33 Ibidem, s. 71-72.

${ }^{34}$ Ibidem, s.72.

35 Ibidem.

36 Ibidem.

${ }^{37}$ Por. ibidem, s. 74.
} 
Korzystanie z dóbr i usług miejskich nie jest bezpłatne. W gminie miejskiej, jako dużej i nowoczesnej grupie, jej powinności związane z udostępnianiem wartości wspólnych jej członkom wykonywane sa przez wyspecjalizowanych funkcjonariuszy. Ich praca wymaga wynagrodzenia, którego źródłem są pieniężne świadczenia mieszkańców w postaci podatków na rzecz gminy miejskiej (bezpośrednich i pośrednich) oraz opłat za korzystanie z należących do niej obiektów $^{38}$. Opłaty te maja jednak zupełnie inny charakter niż te, które za swoje towary lub usługi pobieraja przedsiębiorcy lub spółki prywatne. Nie jest to wymiana ekwiwalentnych wartości, jak w handlu, lecz dostarczanie gminie miejskiej, reprezentowanej przez jej funkcjonariuszy, środków na pokrycie kosztów i konserwację obiektów i urządzeń oferowanych przez nią mieszkańcom. Gmina nie osiąga z tego tytułu zysku. „Opłaty te sa po prostu dostarczaniem miastu przez obywateli środków niezbędnych do dalszego dostarczania im [...] korzyści” ${ }^{39}$. Ich nieekwiwalentność w stosunku do uzyskanych $\mathrm{w}$ zamian korzyści wyraża się $\mathrm{w}$ tym, że ich wartość pieniężna nie pokrywa wartości tych korzyśsi. Charakter ten opłaty te zachowuja nawet wtedy, gdy urządzenie lub zakład komunalny będący do dyspozycji mieszkańców przynosi miastu dochody. Zyski tak osiagane służą polepszeniu sposo$\mathrm{bu}, \mathrm{w}$ jaki funkcjonariusze miejscy administrują i udostępniają dane urządzenie jego użytkownikom, lub też wzbogacają stanowiący własność grupową fundusz gminny przeznaczany na inne cele wspólne. W wypadku świadczeń oferowanych mieszkańcom przez gminę opłaty za korzystanie z nich nie są, zdaniem Znanieckiego, wynagrodzeniem dla wykonujacych je funkcjonariuszy, lecz dostarczają jedynie gminie środków do dalszego świadczenia tych usług ${ }^{40}$.

Znaniecki rozpatruje zjawisko własności grupowej w ścisłym związku z jego aspektem subiektywnym, tzn. sposobem, w jaki wzajemne świadczenia pomiędzy grupą a jej członkami są przez tych ostatnich uświadamiane. Zarówno w refleksji teoretycznej, jak i myśleniu potocznym dostrzec można, jego zdaniem, trzy sposoby ujęcia tych relacji, zawierające zarazem trzy normatywne perspektywy ich postrzegania. Te trzy - jak je nazywa - „idee” to idea równości społecznej, idea proporcjonalności i idea wewnętrznej solidarności. Idea równości oznacza równoważność świadczeń ze strony jednostek i świadczeń ze strony grupy. Nie uwzględnia ona hierarchicznego zróżnicowania pozycji społecznych $\mathrm{w}$ grupie. Idea proporcjonalności (,każdemu co mu się należy”) oznacza, że wartość świadczeń ze strony grupy jest proporcjonalna do wartości świadczeń jednostki. Idea wewnętrznej solidarności ,„żąda [...] więcej niż każe sprawiedliwość od tych, którzy moga dać więcej, daje więcej niż dopuszcza sprawiedliwość tym, którzy potrzebują więcej” ${ }^{41}$.

Idee te moga jednak także stać się elementami praktyki życia społecznego, poprzez wpływ, jaki wywierają na działania ludzkie, w szczególności działania i decyzje organizacyjne kierownictwa i - używając określenia Webera - ,sztabu administracyjnego" grupy. Stają się one wtedy zasadami funkcjonowania

\footnotetext{
${ }^{38}$ Por. ibidem, s. 71.

${ }^{39}$ Ibidem, s. 73.

40 Por. ibidem.

${ }^{41}$ Ibidem, s. 80.
} 
własności wspólnej grupy. Znaniecki sądzi, że w wypadku miasta rolę decydująca odgrywają stosunki własności oparte na zasadzie solidarności wewnętrznej. „Nie mówiąc już o takich grupach, jak religijne lub narodowe, nawet $\mathrm{w}$ gminie miejskiej, grupie bardzo zracjonalizowanej w myśl schematyzmu ekonomicznego, najłatwiej nadającego się do przeprowadzenia idei sprawiedliwości, jeśli nie równości, jeszcze zasada solidarności wewnętrznej przeważa, choć już jej członkowie nie zdają sobie z tego wyraźnie sprawy" ${ }^{42}$.

Można zatem uznać wymienione zasady za formy własności wspólnej. Przykładu własności opartej na zasadzie równości w analizie Znanieckiego nie znajdujemy, przynajmniej w postaci czystej. Jej ilustracja mogłaby być (hipotetyczna) zapomoga przyznana przez władze miasta $\mathrm{w}$ tej samej wysokości wszystkim jego mieszkańcom. Zbliżają się do tej formy wszystkie dostępne dla ogółu obiekty, z których korzysta się bezpłatnie w podobnym zakresie (np. usługi edukacyjne). Własność miejską opartą na zasadzie proporcjonalności reprezentuje większość wymienionych przez Znanieckiego form: wodociagi i dostawa wody, komunikacja miejska i inne formy usług płatnych (zakres, w jakim z nich korzystamy, jest proporcjonalny do wnoszonych opłat). Wreszcie za własność opartą na zasadzie solidarności wewnętrznej uznać trzeba zapomogi dla ubogich i bezrobotnych, domy noclegowe dla ubogich, podwyższone stawki podatkowe dla zamożnych.

Klasyfikacja ta nie uwzględnia jednak dwóch innych form korzystania z własności wspólnej. Pierwsza stanowiłyby obiekty zarówno dostępne, jak i użytkowane powszechnie i niewymagające rekompensaty ze strony korzystających. Formy tej nie można uznać za reprezentująca formę równościowa (Znaniecki zakładał w niej świadczenia użytkowników, których tu nie ma), lecz co najwyżej za jej specyficzny wariant. Ponadto trzeba odróżnić sytuację, gdy zakres korzystania użytkowników jest podobny, od takiej, gdy jest on faktycznie zróżnicowany. Ściśle rozumiana forma równościowa zakłada identyczny zakres korzystania z własności wspólnej, tymczasem w rzeczywistości mogą się one znacznie różnić (ktoś spędza czas w parku codziennie, ktoś inny - tylko wyjątkowo).

Możemy zatem wyodrębnić powszechne i ograniczone formy korzystania ze wspólnej własności (wykraczającej poza jej formę gminną):

1. Formy powszechne:

- powszechna forma równościowa nierekompensowana - wszyscy korzystaja $\mathrm{w}$ tym samym (podobnym) stopniu, nikt nie płaci (publiczna edukacja podstawowa),

- powszechna forma równościowa rekompensowana - wszyscy korzystaja $\mathrm{w}$ tym samym stopniu, płaca tyle samo (powszechne świadectwa udziałowe),

- powszechna forma swobodna nierekompensowana - wszyscy korzystaja w różnym stopniu, nikt nie płaci (ulice i place centrum miasta),

- powszechna forma swobodna rekompensowana (forma proporcjonalnościowa) - wszyscy korzystaja w różnym stopniu, płaca odpowiednio do zakresu korzyści (wodociągi),

- powszechna forma solidarnościowa (zniżki emeryckie, zapomogi itd.).

42 Ibidem. 


\section{Formy ograniczone:}

Oznaczają one sytuację zmonopolizowania korzystania z fragmentu wspólnej własności przez pewną kategorię członków i tym samym faktycznego wykluczenia z niego innych kategorii. Może tak być tylko w sytuacji formalnej powszechnej dostępności tych obiektów i faktycznego braku możliwości lub potrzeby korzystania z nich przez część populacji.

- ograniczona forma równościowa nierekompensowana (część populacji korzysta $\mathrm{w}$ tym samym stopniu, nikt nie płaci),

- ograniczona forma równościowa rekompensowana (część populacji korzysta $\mathrm{w}$ tym samym stopniu, płaca tyle samo),

- ograniczona forma swobodna nierekompensowana (korzystanie w różnym stopniu) - ścieżki rowerowe,

- ograniczona forma swobodna rekompensowana, czyli proporcjonalnościowa (korzystanie i opłaty zróżnicowane).

Wreszcie uwzględnić należy także aspekt, który uszedł uwadze Znanieckiego. Chodzi o różnicę między formalną a faktyczną dostępnością obiektów publicznych. Istnieją mianowicie takie formy korzystania z własności wspólnej, które odnoszą się do obiektów oferowanych bezpłatnie i formalnie dostępnych dla wszystkich, faktycznie jednak użytkowanych tylko przez część populacji. Po pierwsze, chodzi tu o obiekty zaspokajające potrzeby konsumpcyjne mieszkańców (np. parki i tereny zielone, ścieżki rowerowe, biblioteki). Po drugie jednak, także o takie, które przekształcane zostają w prywatne obiekty ekonomiczne (środki produkcji, handlu i usług). Od poprzedniej (ogólnej) formy różniłaby się ona swoją partykularnością - Weber powiedziałby, że stosunek społeczny gminy miejskiej jest tu zamknięty do wewnątrz, czyli że następuje apropriacja szans korzystania z tych obiektów przez pewną część jego uczestników.

Znaniecki zalicza do własności miejskiej ogół obiektów tworzących tzw. własność komunalną oraz fundusz pieniężny przeznaczony na utrzymanie tych obiektów oraz opłacenie usług świadczonych przez gminę mieszkańcom. Część tego majątku stanowią obiekty materialne dziedziczone przez pokolenie aktualne po pokoleniach poprzednich, źródłami pozostałej części są opłaty za użytkowanie tych obiektów i usługi oferowane mieszkańcom oraz podatki. Podobnie jak teoretycy praw własności Znaniecki uznaje podatki za rodzaj niezbędnych kosztów nakładanych na członków wspólnoty, które przeznaczone są na administrowanie własnością wspólną - kosztów wyrównywanych z nadwyżką przez korzyści płynące z użytkowania tej ostatniej.

Tymczasem podatek można traktować nie jako wyraz przekształcania części majątku prywatnego we własność wspólną, lecz formę funkcjonowania samej tej własności. Zauważył to już Comte, krytykujący prawniczą teorię własności za nadawanie zbyt absolutnego sensu stosunkom własności prywatnej. „Zawsze i wszędzie, w większym lub mniejszym stopniu, społeczeństwo ingerowało w sprawy zarządzania własnością celem podporządkowania jej potrzebom społecznym. Jedną $\mathrm{z}$ form udziału społeczeństwa w każdym prywatnym majątku jest podatek. [...] Inny powszechny zwyczaj dowodzi, że w pewnych skrajnych wypadkach wspólnota uważa się nawet za uprawnioną do 
zagarnięcia całej prywatnej własności” ${ }^{43}$. Ten ostatni wypadek uznać można za wyrażający nadrzędną rolę własności wspólnej w stosunku do prywatnej. Ten pierwszy jednak jako rodzaj współwłasności. Także historycy francuscy XIX w. uznawali podatek za formę partycypacji społeczeństwa we własności prywatnej. Wprowadzili rozróżnienie korporalnej i niekorporalnej własności królewskiej. Tę pierwszą reprezentowały wydzielone przestrzennie obszary ziemskie i zakłady wytwórcze, tę drugą - obiekty prywatne (przede wszystkim ziemia), których właściciele zobowiązani byli do uiszczania na rzecz króla podatków i innych powinności. Te obszary prywatnej własności były zatem współwłasnością króla, a płynące $\mathrm{z}$ nich dochody - formą korzystania z nich przez władcę. Jako że własność królewska była kategorią prawną, za którą kryła się po części własność ogólnospołeczna, można uznać własność niekorporalną za pewną formę własności wspólnej.

Również dziś systemy podatkowe pełnia, zdaniem Kozyra-Kowalskiego, funkcje analogiczną. „Ekonomicznym współwłaścicielem wszystkich typów prywatnej własności środków produkcji i siły roboczej jest w nowoczesnych społeczeństwach państwo, czyli w rzeczywistości wspólnota narodowa. Staje się ona takim podmiotem własności przede wszystkim za pomoca systemu podatkowego" ${ }^{44}$. Państwo reprezentujące wspólnotę narodową gromadzi dochody płynące $\mathrm{z}$ jego własności $\mathrm{w}$ formie funduszy pieniężnych, które następnie przekształcane są w różne formy własności prywatnej lub wspólnej, zależnie od celów, na jakie zostaja przeznaczone. Oznacza to, że współczesne państwo pobiera podatki jako współwłaściciel przedsiębiorstw, ziemi, nieruchomości, a także siły roboczej wszystkich pracujących. Prywatni właściciele obiektów podlegających opodatkowaniu są nimi zatem tylko w sensie prawnym, faktycznie współwłaścicielem środków produkcji, towarów, ziemi, budynków itd. jest państwo, czyli wspólnota narodowa. Także pracownicy najemni zobowiązani do płacenie podatków nie sa pełnymi, lecz tylko częściowymi właścicielami swojej siły roboczej. W odróżnieniu od nich suwerennymi właścicielami swojej siły roboczej byli natomiast robotnicy dziewiętnastowieczni, których system podatkowy nie obejmował. Dziś status taki można przypisać jedynie zatrudnionym w szarej strefie.

To samo, z zachowaniem proporcji, odnieść można do funduszy miejskich pochodzących z podatków. Przeznaczenie ich na cele publiczne oznacza, że te obiekty prywatnej własności mieszkańców miasta, których to właściciele płaca z tytułu ich posiadania podatki, nie sa ich pełną własnością, lecz współwłasnością miasta. Inaczej mówiąc, ogół bądź część obywateli miasta jest współwłaścicielem prywatnych obiektów należących także do innej części tych obywateli. Jak jednak wynika z przedstawionej wyżej klasyfikacji form korzystania z własności wspólnej, własność o charakterze formalnie powszechnym może wprawdzie także realnie służyć potrzebom wspólnym, ale może również być rzeczywiście monopolizowana przez węższe grupy użytkowników, a nawet przekształcana w ich własność prywatną.

${ }^{43}$ A. Comte, Rozprawa o duchu filozofii pozytywnej. Rozprawa o catoksztatcie pozytywizmu, tłum. B. Skarga, Warszawa 1973, s. 305-306.

44 S. Kozyr-Kowalski, Socjologia..., s. 178. 
Znaniecki nie idzie tak daleko, uznając za własność miejską same tylko zgromadzone $\mathrm{w}$ formie podatków fundusze. Jednak także na gruncie takiej interpretacji możliwe jest przekroczenie poziomu ogólności traktującego zakres korzystania $\mathrm{z}$ własności komunalnej jedynie w kategoriach ilościowych i dostrzeżenie, że część użytkowników własności miejskiej może uczynić z niej źródło zarobkowania. W jego analizie pojawiaja się wprawdzie przedsiębiorcy, ale tylko jako strony prywatnej umowy handlowej z administracja miejska, w swojej roli użytkowników własności miejskiej nie różnią się natomiast od pozostałych mieszkańców. Być może uznał on, że cele badań, w kontekście których budował swoja koncepcję własności, nie wymagały dalszego jej rozwinięcia (nie znalazł takich wypadków w wypowiedziach konkursowych), być może też traktował badanie takich relacji za przekraczające granice socjologii.

\section{WIELKOMIEJSKA WŁASNOŚĆ KOMUNALNA}

Najważniejszą formą własności wspólnej jest własność komunalna, mająca zarówno postać korporalną, jak i niekorporalną. Pierwsza obejmuje obiekty materialne, ekonomiczne i pozaekonomiczne oraz środki pieniężne pochodzące z opłat za ich użytkowanie. Na drugą składają się udziały w nieruchomościach oraz majątku przedsiębiorstw jak również sile roboczej mieszkańców, które przez system podatków przybierają także formę pieniężną. Udostępnianie tych środków mieszkańcom i ich odtwarzanie jest w rękach funkcjonariuszy miejskich. Oprócz niej istnieje też drugi rodzaj własności wspólnej, prawnie i organizacyjnie wyodrębniony - własność narodowa (,,państwowa” - urządzenia i przedsiębiorstwa gospodarcze, policja, poczta, służba zdrowia). Jej funkcjonowanie finansowane jest także z podatków, lecz nie, jak w pierwszym wypadku, płaconych przez mieszkańców miasta, lecz przez ogół mieszkańców kraju. Faktycznie jednak z obiektów do niej należących nie korzystają wszyscy, którzy je finansuja, lecz mieszkańcy miasta. Dlatego można je także uznać za segment własności miejskiej. To, że podmiot korzystający różni się od podmiotu finansującego, mogłoby sugerować istnienie jakiejś formy wyzysku większej społeczności przez mniejsza, gdyby nie to, że mieszkańcy miasta finansowanego w ten sposób współfinansują za pomocą tego samego podatku własność komunalną innych miast i ośrodków.

Zarządzany przez komunalnych i państwowych funkcjonariuszy majątek trwały i finansowy miasta jest udostępniany formalnie wszystkim jego mieszkańcom. W rzeczywistości korzystanie z niego jest często ograniczone do niektórych tylko ich kategorii. Te dwie sytuacje można z kolei podzielić na świadczenia jednorazowe i ciagłe, a te z kolei - na odpłatne i nieodpłatne. Schematycznie mamy zatem następujące warianty:

\section{Formy powszechne}

1.1. Forma powszechna jednorazowa nieodpłatna - wszyscy korzystaja w tym samym zakresie, nikt nie płaci (forma hipotetyczna).

1.2. Forma powszechna jednorazowa odpłatna - wszyscy korzystaja $\mathrm{w}$ tym samym zakresie, płaca tyle samo (forma hipotetyczna; na poziomie własności publicznej ogólnonarodowej - świadectwa udziałowe). 
1.3. Forma powszechna swobodna nieodpłatna - wszyscy korzystają w różnym zakresie, nikt nie płaci (ulice i place w centrum miasta).

1.4. Forma powszechna swobodna odpłatna - wszyscy korzystają w różnym zakresie, płaca proporcjonalnie do zakresu korzystania (wodociagi, kanalizacja).

\section{Formy ograniczone}

2.1. Forma ograniczona jednorazowa nieodpłatna - część populacji korzysta w tym samym zakresie, nikt nie płaci (szczepienia, badania lekarskie spowodowane zagrożeniem epidemiologicznym).

2.2. Forma ograniczona jednorazowa odpłatna - część populacji korzysta w tym samym zakresie, płacą tyle samo (wielkie koncerty muzyczne, finansowane lub współfinansowane przez miasto).

2.3. Forma ograniczona swobodna nieodpłatna - część populacji korzysta w różnym zakresie, nikt nie płaci (lasy miejskie, ogród botaniczny).

2.4. Forma ograniczona swobodna odpłatna - część populacji korzysta w różnym zakresie, płaca proporcjonalnie do zakresu korzystania (palmiarnia, teatry, muzea, opera).

3. Formy solidarnościowe

Z założenia przeznaczone dla wybranej części populacji - zniżki emeryckie, zapomogi.

Pierwszą fazą analizy sposobów korzystania z własności komunalnej jest zagadnienie jej prywatyzacji, czyli przekształcania części tej własności w elementy różnych form własności prywatnej: kapitalistycznej własności środków produkcji, handlu i usług i samodzielnej prywatnej własności środków produkcji, handlu i usług. Przykładem prywatyzacji pierwszego rodzaju sa centra handlowe. W Poznaniu zarówno systemy kanalizacji, jak i drogi dojazdowe do tych centrów (M1, King Cross, Franowo) zostały w części lub całkowicie sfinansowane $\mathrm{z}$ funduszy miejskich. W wypadku Centrum M1 linia autobusowa zapewniająca komunikację między centrum miasta a centrum handlowym i finansowana przez właścicieli należących do niego marketów została zastąpiona znacznie sprawniejszą linią tramwajową, zbudowaną całkowicie ze środków miejskich - nie uszczupliła kapitałów marketów, ale wręcz pozwoliła im zaoszczędzić znaczne środki finansowe. Elementami prywatnej własności są nie tylko specjalne trasy i linie dojazdowe, lecz także cała sieć ulic i dróg miejskich. Maja one charakter wielofunkcyjny: służą zarówno jako trasy transportowe prywatnych towarów, jak i trasy transportu osobistego mieszkańców. Prywatni przedsiębiorcy, dla których transport towarów jest elementem kosztów, moga w ten sposób je obniżyć. Korzystanie z bezpłatnych dróg miejskich oznacza formę ich prywatyzacji. Wreszcie także tabor tramwajowy i autobusowy, utrzymywany $z$ opłat i dotowany przez miasto, jest elementem kosztów dojazdu do pracy pracowników zarówno przedsiębiorstw prywatnych, jak i instytucji publicznych i w tej mierze jest także prywatyzowany. Wyższy poziom tych opłat przysporzyłby kosztów (wynagrodzeń dla tych pracowników) zarówno prywatnym, jak 
i publicznym pracodawcom. To samo dotyczy urządzeń wodociąowych i kanalizacyjnych, które są finansowane $\mathrm{z}$ opłat za ich użytkowanie i dotacji miejskich. Użycie wody i kanalizacji do celów zarobkowej działalności ekonomicznej oznacza także prywatyzację części majątku komunalnego.

Druga faza analizy odnosi się do monopolizacji (w terminologii Weberowskiej: apropriacji) użytkowania własności komunalnej w sferze konsumpcji. Można w niej wyodrębnić kilka aspektów. Aspekt klasowo-stanowy polega na tym, że pewna klasa (bądź stan) lub klasy (stany) monopolizuja (całkowicie lub $\mathrm{w}$ wysokim stopniu) korzystanie z pewnych formalnie dostępnych powszechnie typów własności miejskiej. Wariantem kryterium klasowego jest jego forma negatywna: przedstawiciele określonych klas lub stanów nie korzystaja z określonej formy własności komunalnej. Można tu ponownie wymienić przykład komunikacji miejskiej: nie korzystaja z niej (lub co najwyżej korzystają okazjonalnie) menedżerowie wielkich firm i zamożni przedsiębiorcy. Z finansowanych z budżetu miasta przedstawień Teatru Ósmego Dnia nie korzystają robotnicy, a zapewne także członkowie innych klas. Noclegownie dla bezdomnych stają się grupową własnością poznańskiej ,,podklasy”. Budynki i urządzenia należące do wyższych uczelni są faktycznie własnością grupową ich studentów i wykładowców.

Aspekt przestrzenny oznacza przekształcanie własności komunalnej we własność grupową mieszkańców poszczególnych dzielnic: parki, place zabaw dla dzieci, szkoły podstawowe, klubu osiedlowe, przychodnie medyczne (co nie wyklucza oczywiście okazjonalnego korzystania z nich osób spoza dzielnicy). $\mathrm{Na}$ ten typ grupowego zróżnicowania własności nakłada się często aspekt etniczny. Wreszcie pozostaje do zbadania, jakie inne grupy moga faktycznie zawłaszczać określone części materialnej lub finansowej własności miejskiej.

Czy zatem coś z niej pozostaje? Po pierwsze to, co realizuje się poprzez powszechne formy korzystania. Po drugie, te formy ograniczone, które nie sa trwale monopolizowane przez określoną grupę mieszkańców, lecz których beneficjenci się zmieniaja.

\section{PODSUMOWANIE}

Spośród istniejących ujęć problematyki własności wybrałem trzy, które uznałem za przydatne do postawienia problemu własności komunalnej. Założenia ogólnej teorii własności oparłem na koncepcji Kozyra-Kowalskiego, będącej rodzajem syntezy klasycznych przyczynków do tej problematyki i zawierającej też obecny u Marksa, po części u Simmla i Znanieckiego, wątek własności jako bezekwiwalentnego korzystania z obiektów materialnych i niematerialnych. Koncepcja ta, występująca u tych autorów jedynie w postaci zalążkowej, została przez Kozyra-Kowalskiego uznana za ogólną zasadę stosunku własności, zarówno $\mathrm{w}$ jej postaci ekonomicznej (produkcyjnej), jak i konsumpcyjnej. Teoria praw własności, pomimo swoich słabości, jest jedną z niewielu koncepcji, która 1) oparta jest na szeroko prowadzonych badaniach empirycznych, 2) w sposób jasny (co nie znaczy, że w pełni zadowalający) definiuje pojęcia własności 
prywatnej i własności wspólnej, dostrzega również pozytywne i negatywne strony zarówno jednej, jak i drugiej. Ważnych inspiracji do analizy własności komunalnej dostarcza również koncepcja własności gminnej Znanieckiego (mało znana nawet wśród znanieckologów). Jest ona pewną wstępną próbą zastosowania do analizy własności publicznej koncepcji własności jako gratisowego korzystania. Ostatnia część artykułu prezentuje próbę systematyzacji problematyki własności komunalnej, w szczególności typów występującej tam własności wspólnej oraz relacji pomiędzy nimi, a warunkującymi ją bądź wywodzącymi się z niej formami własności prywatnej. Nie pretenduje ona do rozwiązania wszystkich związanych z tym problemów. Traktuję tę propozycję teoretyczną jako punkt wyjścia badań empirycznych, które pozwoliłyby na jej rozwinięcie, a to z kolei - na rozwinięcie ogólnej teorii własności wspólnej.

dr Andrzej Przestalski

Uniwersytet im. Adama Mickiewicza w Poznaniu

\section{COMMUNAL OWNERSHIP VS COMMON OWNERSHIP IN SOCIOLOGICAL PERSPECTIVE}

\section{Summary}

The sociological perspective in ownership analysis adopted by the author is neither the only one nor a dominant one in sociology. It refers to Stanisław Kozyr-Kowalski's ownership theory according to which ownership means a free (i.e. unpaid) benefit from an object, no matter what the legal property status of the beneficiary. Communal ownership is a form of common ownership of which two sociologically valuable theories are presented in the paper. One, known as the property rights theory, makes a sociologically significant distinction between communal property and public (state) property. While the former is a property of resources that any member of the group can use without limits, the latter is a property of scarce resources, the use of which is regulated by specially nominated bodies. The other theory presented in the paper is Florian Znaniecki's theory of municipal ownership. Its merit lies in emphasising the fact that common ownership means making group values freely accessible to its members. Using municipal ownership as an example he shows that fees charged by the city officers or municipally run institutions do not serve to multiply the profit of the city but only to cover the costs of services performed for the town dwellers. The principal weakness of both theories, according to the author of the paper, is closing the analysis on the level of public ownership (general or group), neglecting (i) the process of actual privatising its elements by private economic subjects, (ii) the process of monopolising its elements by smaller groups of city dwellers. Both are analysed in the last part of the paper. 
Copyright of Journal of Law, Economics and Sociology is the property of Faculty of Law and Administration of Adam Mickiewicz University in Poznan and its content may not be copied or emailed to multiple sites or posted to a listserv without the copyright holder's express written permission. However, users may print, download, or email articles for individual use.

Właścicielem praw autorskich do „Ruchu Prawniczego, Ekonomicznego i Socjologicznego” jest Wydział Prawa i Administracji Uniwersytetu im. Adama Mickiewicza w Poznaniu. Zawartość czasopisma nie może być kopiowana, przesyłana do innych stron internetowych bądź zamieszczana na blogach bez pisemnej zgody wydawcy. Niemniej artykuły można drukować, kopiować lub przesyłać w formie elektronicznej na własny użytek. 